http://heanoti.com/index.php/hn

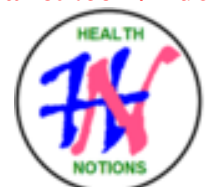

RESEARCH ARTICLE

URL of this article: http://heanoti.com/index.php/hn/article/view/hn30401

\title{
Consumption of Folic Acid, B12 and Menstruation Pattern with Anemia Phenomenon in Young Women in Surabaya
}

\begin{tabular}{c} 
Irine Christiany ${ }^{1(\mathrm{CA})}$, Kiaonarni Ongko Waluyo ${ }^{2}$ \\
${ }^{1(\mathrm{CA})}$ Department of Nursing, Health Polytechnic of Surabaya, Indonesia; irinesby64@ gmail.com (Corresponding \\
Author) \\
${ }^{2}$ Department of Nursing, Health Polytechnic of Surabaya, Indonesia; kiaonarni@ gmail.com \\
\hline
\end{tabular}

\section{ABSTRACT}

Consumption of folic acid intake, B12 and the pattern of menstruation are factors causing the occurrence of anemia, vitamin B12 and folic deficiency often occurs in young women. Deficiency of one or several nutrients such as iron, vitamin B12, folic acid, and vitamin C, which is necessary for the formation of nutrients can cause nutritional anemia. The purpose of study was to know the intake of folic acid intake, Vitamin B12 and menstruation pattern with the incidence of Anemia in young women in Surabaya Junior High School. Research method was cross sectional approach. The study population of all female students who have menstruated in Surabaya Junior High School was taken by simple random sampling. The research instrument was questionnaire by 24-hour Food Recall and FFQ complement data that could not be obtained through 24-hour memory, menstrual pattern questionnaires and hemoglobin results by measuring hemoglobin (HB) by cyanmethemoglobin method. Data analysis was using logistic regression test. The result was 19.007 ( $\mathrm{p}=0.000$; $\mathrm{OR}=31.000-; 95$ percent $\mathrm{CI}=4.002-240.150)$, this means there was a significant association between vitamin B12 intake and the incidence of anemia $(\mathrm{p}<0.05)$, and the menstruation pattern was $10.340(\mathrm{p}=0.001 ; \mathrm{OR}=$ 4.846-; 95 percent $\mathrm{CI}=1.897$ - 12.379), this means there was a significant relationship between the pattern of menstruation and the incidence of anemia $(\mathrm{p}<0.05)$. Vitamin B12 intake and menstruation pattern significantly influenced the incidence of anemia $(\mathrm{P}=<0.05)$

Keywords: Folic acid, Vitamin B12, Menstruation pattern, Anemia

\section{INTRODUCTION}

\section{Background}

Anemia is a major global problem, especially in developing countries. These health problems are still unsolved and continue to affect the health, quality of life, and work capacity of people around the world. In developing countries, vitamin B12 deficiency is a significant problem, among vitamins B, B6, folic, and B12 together and mutually beneficial in various biochemical and molecular functions including one-carbon metabolic system. This vitamin deficiency causes various chronic diseases including megaloblastic anemia ${ }^{(1)}$.

Consumption of folic acid intake, B12 and the pattern of menstruation are factors causing nutritional anemia, vitamin B12 and folic acid deficiency often occurs in young women. Age 12-14 years may be in the transition from adolescence to adolescence, which is the period of identity and teenage search quickly recorded by the environment. Anxiety will shape the body making teenagers deliberately not eating or choosing to eat out. 4 This habit can be done in women who have low nutritional disorders and are at risk for their health, including anemia. Based on Riskesdas in 2007 the prevalence of pregnancy anemia time $\leq 14$ years in Indonesia as much as $12.8 \%{ }^{(2)}$.

The prevalence of anemia in Indonesia is $21.7 \%$, males are $18.4 \%$ and females are higher at $23.9 \%$. The proportion of anemia by age $15-24$ years is $18.4 \%{ }^{(3)}$. The results of Permaesih ${ }^{(4)}$ mentioned the prevalence of anemia in adolescents by $25.5 \%$ with details of $21 \%$ of men and $30 \%$ in women. Various factors can also affect the occurrence of iron nutritional anemia, including menstrual patterns, knowledge about anemia, and nutritional

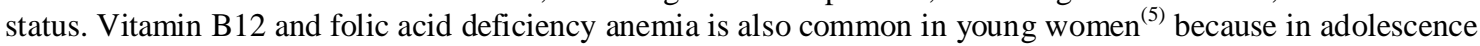
there is an increase in iron demand due to growth, the presence of menstruation, and often limit eating 
consumption. When the food intake is less than many iron reserves are broken down. Such circumstances can accelerate the occurrence of anemia, which can cause physical activity in students decreased. Anemia is a condition in which the hemoglobin (HB) level in the blood is lower than the normal value for the group of people by age and sex, in normal hemoglobin women is $12 \mathrm{~g} / \mathrm{dl}^{(6)}$.

Lack of vitamin intake in our daily menu can lead to the occurrence of anemia problems. Vitamin B12 and folic acid are indispensable in the process of formation of red blood cells. This vitamin is known as appetite guard and prevents the occurrence of anemia (less blood) by forming red blood cells ${ }^{(7)}$.

Lack of folic acid can cause megaloblastic anemia. Adequate consumption of folic acid can decrease serum homocysteine and can be protection against coronary heart disease. In addition to folic acid, vitamin B6 is one part of the vitamin B complex that plays a role in the formation of red blood cells and is also needed in chemical reactions needed to digest proteins ${ }^{(8)}$.

Disadvantages of one or several nutrients such as iron, vitamin B12, folic acid, protein, and vitamin C, which are necessary for the formation of nutrients can cause nutritional anemia. Conditions such as excess blood loss, blood cell damage or decreased blood cell production are a symptom of anemia. The occurrence of anemia can be seen through hemoglobin and hematocrit ${ }^{(9)}$. Other factors that may affect the occurrence of anemia include menstrual patterns, knowledge about anemia, and nutritional status ${ }^{(10)}$. Factors of nutritional status affect the occurrence of anemia then the consumption of food as a nutritional intake of young women need to get the main concern ${ }^{(11)}$. Factors that affect anemia is also affected by the increased body needs, due to chronic illness and blood loss due to menstruation and parasitic infections (worms) ${ }^{(12)}$.

\section{METHODS}

This study was using analytical survey research with cross sectional survey design. The research used quantitative approach of data processing with descriptive and analytic. The purpose of cross-sectional approach was the population of all students in 48 Junior High School Surabaya. The sample of research was part of 48 Junior High School students in Surabaya. The sampling technique used was simple random sampling.

\section{Design and Research Subjects}

Based on the research objectives, the design of the study according to the time was a cross sectional study because it was done one time observation to know the relationship between consumption intake variable at folic acid nutrient, vitamin B12 and menstrual pattern with anemia (Hemoglobin).

\section{Location and Time Research}

The research was conducted at 48 Junior High School Surabaya. The location is at Bratang Wetan 36 Street, 48 Junior High School Surabaya is located in Wonokromo District. The female gender numbers were 519 persons. The study was conducted from May to October 2017.

\section{Research Variable}

The variables were the intake of Folic acid nutrient, vitamin B12 and menstrual pattern with the incidence of anemia (Hemoglobin levels).

\section{Types and Methods of Data Collection}

The research instrument used was the measurement of food intake by assessing the need of Nutrition Adequacy Ratio (AKG). Data collection tools used in this research were questionnaire, 24 hour food recall form and measuring hemoglobin level $(\mathrm{Hb})$ of respondent by using cyanmethemoglobin; 24 hours food recall method was done by recording the type and amount of food consumed in the period 24 hours.

\section{Data Analysis}

Methods of data analysis performed are as follows:

1. Descriptive analysis: Data were presented in the form of frequency table include the incidence of anemia, intake of folic acid nutrients, Vitamin B12 and menstrual pattern.

2. Multivariable analysis: to see the relationship between independent variables together to the dependent variable and which variable is the most dominant influence the occurrence of anemia with statistical test used logistic regression. 


\section{RESULTS}

Consumption of Folic Acid intake, vitamin B12 intake, menstruation pattern

Table 1. Distribution of age, folic acid intake, B12 intake, menstruation and $\mathrm{Hb}$

\begin{tabular}{|c|c|c|c|}
\hline \multirow[b]{2}{*}{$\mathrm{NO}$} & \multirow{2}{*}{ Characteristic } & \multicolumn{2}{|c|}{ Frequency } \\
\hline & & $n=100$ & $\%$ \\
\hline \multirow{2}{*}{1} & \multirow{2}{*}{ Intake of Folic Acid } & 73 & 73 \\
\hline & & 27 & 27 \\
\hline \multirow{2}{*}{2} & \multirow{2}{*}{ Intake of B12 } & 65 & 65 \\
\hline & & 35 & 35 \\
\hline \multirow{2}{*}{3} & \multirow{2}{*}{ Menstruation Pattern } & 50 & 50 \\
\hline & & 50 & 50 \\
\hline \multirow{2}{*}{4} & \multirow{2}{*}{ Hemoglobin (HB) } & 32 & 32 \\
\hline & & 68 & 68 \\
\hline
\end{tabular}

Consumption of folic acid intake is less. Consumption of vitamin B12 is less while consumption of vitamin B12 is sufficient. Menstruation in abnormal pattern of students is the same as the normal menstruation. The hemoglobin is also normal. This research is in line with Kulkarni et al. the prevalence of anemia was slightly higher in girls under 14 years $(92.2 \%)$ but menarche and menarche age status was not significantly associated with anemia ( $p$-value $>0.05)^{(13)}$. This may be due to the very high prevalence of anemia in the study group. Malnutrition anemia that is not good for the individual affects the health, quality of life, and work capacity of billions of people around the world. Anemia in adolescents can have an impact on the decrease of work productivity or academic ability in schools, due to lack of learning and concentration. Vitamin B12 and folic acid deficiency anemia is also common in young women ${ }^{(5)}$.

\section{The Relationship of Folic Acid Intake with Anemia Phenomenon}

Table 2. Relationship of folic acid intake with anemia

\begin{tabular}{|c|c|c|c|c|c|c|c|c|c|c|}
\hline \multirow{3}{*}{$\begin{array}{c}\text { Folic acid } \\
\text { intake }\end{array}$} & \multicolumn{4}{|c|}{ Anemia phenomenon } & \multirow{2}{*}{\multicolumn{2}{|c|}{ Total }} & \multirow{3}{*}{ OR } & \multirow{3}{*}{ CI } & \multirow{3}{*}{$X^{2}$} & \multirow{3}{*}{$\mathrm{P}$} \\
\hline & \multicolumn{2}{|c|}{ Anemia } & \multicolumn{2}{|c|}{ Normal } & & & & & & \\
\hline & $\mathrm{n}$ & $\%$ & $\mathrm{n}$ & $\%$ & $\mathrm{n}$ & $\%$ & & & & \\
\hline Poorly & 31 & 42.5 & 42 & 57.5 & 73 & 100 & \multirow{3}{*}{19.190} & \multirow{3}{*}{$\begin{array}{c}2.469- \\
149.146 .\end{array}$} & \multirow{3}{*}{11.886} & \multirow{3}{*}{0.001} \\
\hline sufficient & 1 & 3.7 & 26 & 96.3 & 27 & 100 & & & & \\
\hline Total & 32 & 32 & 68 & 68 & 100 & 100 & & & & \\
\hline
\end{tabular}

Based on the results of analysis of the results showed that intake of folic acid is less for people experienced anemia. The result of statistical test using chi-square obtained result which means there is a significant relation between folic acid intakes with the incidence of anemia $(p<0.05)$ OR value of folic acid intake means that respondent with folic acid intake less risk of anemia than respondent with enough folic acid intakes.

\section{The Relationship of Vitamin B12 Intake with Anemia Phenomenon}

Table 3. Intake of vitamin B12 with anemia phenomenon

\begin{tabular}{|c|c|c|c|c|c|c|c|c|c|c|}
\hline \multirow{3}{*}{$\begin{array}{c}\text { Intake of } \\
\text { vitamin B12 }\end{array}$} & \multicolumn{4}{|c|}{ Anemia phenomenon } & \multirow{2}{*}{\multicolumn{2}{|c|}{ Total }} & \multirow{3}{*}{ OR } & \multirow{3}{*}{$\mathrm{CI}$} & \multirow{3}{*}{$X^{2}$} & \multirow{3}{*}{$\mathrm{P}$} \\
\hline & \multicolumn{2}{|c|}{ Anemia } & \multicolumn{2}{|c|}{ Normal } & & & & & & \\
\hline & $\mathrm{n}$ & $\%$ & $\mathrm{n}$ & $\%$ & $\mathrm{n}$ & $\%$ & & & & \\
\hline Poorly & 31 & 47.7 & 34 & 52.3 & 65 & 100 & \multirow{3}{*}{31.000} & \multirow{3}{*}{$\begin{array}{c}4.002- \\
240.150\end{array}$} & \multirow{3}{*}{19.007} & \multirow{3}{*}{0.000} \\
\hline Sufficient & 1 & 2.9 & 34 & 97.1 & 35 & 100 & & & & \\
\hline Total & 32 & 32 & 68 & 68 & 100 & 100 & & & & \\
\hline
\end{tabular}

Based on the results of relationship analysis showed that intake of vitamin B12 is less and experienced anemia. Statistical test results using chi-square obtained results which mean there is a significant relationship 
between vitamin B12 intakes with the incidence of anemia or that value of vitamin B12 means that respondents with vitamin B12 intake are less likely to have anemia than respondents with adequate vitamin B12 intake.

\section{The Relationship of Menstruation Patterns with Anemia Phenomenon}

Table 4. Relationship of menstrual pattern with anemia phenomenon

\begin{tabular}{|c|c|c|c|c|c|c|c|c|c|c|}
\hline \multirow{3}{*}{$\begin{array}{l}\text { Menstrual } \\
\text { pattern }\end{array}$} & \multicolumn{4}{|c|}{ Anemia phenomenon } & \multirow{2}{*}{\multicolumn{2}{|c|}{ Total }} & \multirow{3}{*}{ OR } & \multirow{3}{*}{$\mathrm{CI}$} & \multirow{3}{*}{$X^{2}$} & \multirow{3}{*}{$\mathrm{P}$} \\
\hline & \multicolumn{2}{|c|}{ Anemia } & \multicolumn{2}{|c|}{ Normal } & & & & & & \\
\hline & $\mathrm{n}$ & $\%$ & $\mathrm{n}$ & $\%$ & $\mathrm{n}$ & $\%$ & & & & \\
\hline Abnormal & 24 & 48.0 & 26 & 52.0 & 50 & 100 & \multirow{3}{*}{4.846} & \multirow{3}{*}{$\begin{array}{c}1.897- \\
12.379\end{array}$} & \multirow{3}{*}{10.340} & \multirow{3}{*}{0.001} \\
\hline Normal & 8 & 16.0 & 42 & 84.0 & 50 & 100 & & & & \\
\hline Total & 32 & 32 & 68 & 68 & 100 & 100 & & & & \\
\hline
\end{tabular}

Based on the result of relationship analysis showed that menstruation pattern is not normal as many as the students who had normal menstrual pattern. The result of statistic test by using chi-square obtained results which mean there is a significant relationship between menstrual pattern and the incidence of anemia or value of menstruation pattern means respondent with abnormal menstrual pattern at risk of anemia bigger then compared to respondent with normal menstrual pattern. This is in line with the study of Vijayakumar \& Mohammed, of 101 adolescents, there are 40 children who have not menstruated while 61 who have menstruation associated with the incidence of cases of anemia ranging from mild to moderate anemia are statistically significant ${ }^{(14)}$. Various studies have also shown a significant relationship between anemia and menstrual patterns that support our results. According to Demir, for example: a similar study was conducted in Turkey; they reported $26.7 \%$ of girls had irregular periods after 2 years of menarche and $62.2 \%$ of them had at least one irregular bleeding form at this time. Girls at the age of puberty have tremendous physical \& psychological changes. They do not have serious gynecological pathology but menstrual disorders are common. In the normal menstrual cycle theory is 25 to 32 days. About $97 \%$ of women who have their menstrual cycle range from 18 to 42 days. Adolescence is usually irregular menstrual cycle. If the menstrual cycle is less than 18 days or more than 42 days and irregular, usually menstrual cycle is not ovulated. The amount of blood that comes out is affected by age and nutrition. The older the woman's age the more blood that comes out ${ }^{(15)}$.

\section{The Results of Multivariable Analysis}

Table 5. Results multivariate analysis of consumption folic acid intake, vitamin B12 and the pattern of menstruation with hemoglobin levels in female students

\begin{tabular}{ccccc}
\hline \multirow{2}{*}{ Variable } & \multirow{2}{*}{$\operatorname{Exp}(\mathrm{B})$} & \multicolumn{2}{c}{ 95.0\% C. I. } & P (value) \\
\cline { 3 - 4 } & & Lower & Upper & 0.438 \\
Folic acid intake & 2.568 & 0.236 & 27.900 & 0.012 \\
Vitamin B12 intake & 17.255 & 1.890 & 157.498 & 0.020 \\
Menstrual Pattern & 3.410 & 1.208 & 9.622 &
\end{tabular}

Answering the most dominant independent variables was associated with the occurrence of anemia (hemoglobin level), a multivariate analysis was performed, based on bivariate analysis of independent variables that entered a meaningful multivariate analysis with $\mathrm{p}<0.05$. The variable of folic acid intake had the greatest $P$ value $(\mathrm{P}>0.05)$. Where $\mathrm{p}$-value is smaller than the level of significance has been set $(0.05)$ can be interpreted that the relevant variables have a significant influence on the response variable.

\section{DISCUSSION}

\section{Consumption of Folic Acid Intake with the Incidence of Anemia in Female Students}

This study is in line with Sukla's study. In the study obtained results from 674 normocytic subjects, 307 were anemia where each 330 and 71 subjects lacked vitamin B12 and folic acid ${ }^{(16)} .95 \%$ (181/190) of those who lack vitamin B12 in the microcytic category have anemia as in 61\% (19/31) of microcritic folic acid deficiency also suffer from anemia. Among normocytes, 72\% (236/330) of vitamin B12 deficiency is not good, while $78 \%$ (55/71) of folic acid deficiency are anemic. Of all the results obtained from cases of folic acid deficiency all anemia occurs, but in reality the results obtained from female students lacking folic acid intake but less anemia is possible for students to occur due to a lack of one or more nutrients needed for blood formation, (for example 
iron, folic acid, vitamin B12). Lack of folic acid causes a specific anemia form called megaloblastic anemia with high MCV. It is estimated that, in developing countries, folic acid deficiency occurs in $25 \%$ to $72 \%$ of women of childbearing age. Folic acid is present in plant-based foods, e.g. green leafy vegetables, seeds, and so on. However, the problem is the procedure of food preparation (cooking, frying, grinding, grilling) completely destroys the percentage of high folic acid content in food ${ }^{(1)}$. The cause of anemia is not only caused by insufficient nutrients. If the input of sufficient nutrients, but in the process of production of red blood cells is disrupted due to poor functioning of digestion or gastric abnormalities so that important nutrients cannot be absorbed and wasted with dirt, then over time the body will experience anemia.

\section{Consumption of Vitamin B12 Intake with Anemia in Female Students}

This study is in line with a research study in India about the B12 deficiency of our study. Our vitamins were significantly related to the severity of anemia as confirmed by the findings of Patra et al. also research from Kulkarni et al. out of 272 adolescent girls in the study population, $245(90.1 \%)$ girls had anemia ${ }^{(13)}$. The majority of girls $(88.6 \%)$ have mild to moderate anemia and only $1.5 \%$ have severe anemia. B12 severe deficiency has the potential to cause a fatal form of anemia called Pernicious anemia. The body's need for vitamin B12 is as important as iron minerals. This vitamin B12 together with iron serves as an ingredient in the formation of red blood. Even the lack of this vitamin not only triggers anemia, but can interfere with the nervous system. Vitamin B12 deficiency can occur due to interference from our own body or external causes. The gastrointestinal tract will absorb all the nutrients in food, including vitamin B12. Pernicious anemia (anemia due to vitamin B12 deficiency) is a condition where vitamin B12 cannot be absorbed because the stomach cannot produce intrinsic factors, which will combine with vitamin B12 and transport it into the bloodstream. This anemia sometimes occurs because an excessive immune system attacks the stomach cells that produce intrinsic factors (autoimmune reactions).

\section{Menstruation Patterns with Occurrence of Anemia in Female Students}

Various studies have also shown a significant relationship between anemia and menstrual patterns that support our results. A significant relationship was also found between the severity of anemia and helminthiasis similar to findings. For example: a similar study was conducted in Turkey; they reported $26.7 \%$ of girls had irregular periods after 2 years of menarche and $62.2 \%$ of them had at least one irregular form of bleeding at this time. Girls at puberty have extraordinary physical \& psychological changes. They do not have serious gynecological pathology but menstrual disorders often occur. Our limitations are that we only found girls who suffered menstrual disorders after 3 years of menarche; preferably, we invited them at a gynecology clinic to evaluate and treat their menstrual disorders. In theory the menstrual cycle is normally 25 to 32 days. About $97 \%$ of women who have their menstrual cycles range from 18 to 42 days. Adolescence is usually not regular menstrual cycle. If the menstrual cycle is less than 18 days or more than 42 days and is irregular, usually the menstrual cycle does not ovulate. The amount of blood coming out is influenced by age and nutrition. The older the woman's age the more blood comes out ${ }^{(15)}$.

It can be seen that partially, the partial variable of folic acid intake has no significant effect on the incidence of anemia. To know the most dominant variable have an effect on the occurrence of anemia is variable intake of vitamin B12. This study is in line with the study of Kishore et al. a significant reduction in anemia in schoolchildren and the authors felt it was plausible that other micronutrient deficiencies (i.e. vitamin B12 \& folic acid) could be the reason for the ineffectiveness of iron supplementation ${ }^{(16)}$. Therefore, it is important to examine the incidence of vitamin-B12 (vitamin-12) and folic acid deficiency anemia, especially in populations with high levels of malnutrition. Previous studies of indigenous populations from eastern India have revealed that nearly $50 \%$ of the population was deficient in vitamin B12 and $11 \%$ in folic acid. Another newer study from the same region showed $65 \%$ vit-B12 and $27 \%$ of folic acid deficiency. Folic acid deficiency is the most commonly followed by vitamin B12 deficiency \& then iron deficiency. The low intake of these three nutrients is a significant determinant of causing nutritional anemia. Supplementation with not only iron and folic acid but also vitamin B12 is required through a national $\operatorname{program}^{(14)}$.

\section{CONCLUSION}

In this chapter we will describe the conclusions and suggestions based on the results discussed in the previous chapter. Lack of consumption of one or more nutrients such as consuming animal foods (iron, vitamin B12, folic acid, and vitamin C) required for the formation of nutrients play a role in the formation of red blood cells and also in need in chemical reactions in need to digest proteins can cause nutritional anemia, coupled with conditions such as excess blood loss is also a contributing factor to the occurrence of anemia. Researchers suggest: (1) Teenagers in familiarizing the consumption of balanced nutritional food to meet the needs of 
calories and micronutrients according to adolescent age appropriate AKG, especially in young women in addition to the growth period also always get menstruation. (2) Health workers provide health education on balanced nutritional intake by explaining the source and function of food ingredients in iron, folic acid and B12 and vitamin $\mathrm{C}$, explaining the nutritional needs of adolescents for the growth period in accordance with ageappropriate nutritional adequacy rates.

\section{REFERENCES}

1. Milman N. Anemia — still a major health problem in many parts of the world ! 2011;369-77.

2. Indartanti D. Relationship between Nutritional Status and Anemia Occurrence in Young Female Teens (Hubungan Status Gizi Dengan Kejadian Anemia Pada Remaja Putri). J Nutr Coll [Internet]. 2014;3(2):310-316. Available from: http://www.ejournal-s1.undip.ac.id/index.php/jnc/article/view/5438

3. MoH-RI. Basic Health Research 2013 (Riset Kesehatan Dasar (RISKESDAS) 2013). Jakarta: MoH-RI, 2013.

4. Sulistyoningsih H. Nutrition for Mother and Child Health (Gizi untuk Kesehatan Ibu dan Anak). Graha Ilmu; 2010.

5. Corwin JE. Pocket Book of Phatophysiology $3^{\text {rd }}$ ed. (Buku Saku Patofisiologi Ed. 3). Jakarta: EGC; 2009.

6. Adriani M. The Role of Nutrition in the Life Cycle (Peranan Gizi dalam Siklus Kehidupan). Kencana Prenada Media Group; 2012.

7. Citrakesumasari. Anemia Nutrition Problems and Prevention (Anemia Gizi Masalah dan Pencegahannya). 2012. 1-67 p.

8. Sandjaja. Family Health Supplementary Dictionary (Kamus Gizi Pelengkap Kesehatan Keluarga). Jakarta: Kompas; 2009.

9. Dieny FF. Nutritional Problems in Young Female Teens (Permasalahan Gizi pada Remaja Putri). Yogyakarta: Graha Ilmu; 2014.

10. Indartanti D, Kartini A. Relationship between Nutritional Status and Anemia Occurrence in Young Women (Hubungan Status Gizi dengan Kejadian Anemia pada Remaja Putri). J Nutr Coll [Internet]. 2014;3(2):310-6. Available from: http://www.ejournal-s1.undip.ac.id/index.php/jnc/article/view/5438

11. Rumpiati E. The Relationship Between Nutritional Status and Occurrence of Anemia in Young Women in Class 1 of Madiun City Muhammadiyah High School (Hubungan Antara Status Gizi dengan Kejadian Anemia pada Remaja Putri di Kelas 1 SMA Muhammadiyah Kota Madiun). 2010.

12. Masrizal. Iron Deficiency Anemia (Anemia Defisiensi Besi). J Kesehat Masy. 2007;II(1):140-5.

13. Kulkarni M, Durge P, Kasturwar N. Prevalence of Anemia among Adolescent Girls in an Urban Slum. Natl J Community Med. 2012;3(1):108-11.

14. Vijayakumar A, Mohammed M. Iron, Vitamin B12 and Folate Deficiency in Adolescents Having Nutritional Anaemia. J Evol Med Dent Sci J Evol Med Dent Sci. 2014;3(43):10626-33.

15. Sarwono P. Gynecology (Ilmu Kandungan). Jakarta: PT Bina Pustaka Sarwono Prawirohardjo; 2011.

16. Kishore K, Nagar R, Raman R. Vitamin-B12 and Folic Acid Deficiency, Major Contributing Factors for Anemia: A population based study. ESPEN J [Internet]. 2014;9(1):e45-8. Available from: http://dx.doi.org/10.1016/j.clnme.2013.11.003 